\title{
DN \\ . \\ HOW DO WE GET MORE WOMEN ON COMPANY BOARDS?
}

DESPITE PROGRESS IN RECENT YEARS, WOMEN REMAIN UNDERREPRESENTED ON COMPANY BOARDS. THIS IS A PROBLEM: RESEARCH SHOWS THAT COMPANIES WITH WOMEN IN TOP POSITIONS BENEFIT IN NUMEROUS WAYS, INCLUDING THROUGH NETWORKING AND FAMILY-FRIENDLY POLICIES. DR HELEN KOWALEWSKA OF THE UNIVERSITY OF OXFORD IS INVESTIGATING DIFFERENCES IN COUNTRIES' SOCIAL POLICIES TO UNDERSTAND HOW THE UK COULD IMPROVE GENDER DIVERSITY AT THE TOP DECISION-MAKING LEVEL

\section{TALK LIKE A SOCIAL POLICY ANALYST}

BOARD OF DIRECTORS (OR BOARDROOM) - a committee that represents the owners or shareholders of a company and makes important business decisions

BOARDROOM QUOTA - quotas or targets for increasing the proportion of women in the boardroom

EXECUTIVE - the definition of 'executive' differs from company to company but, in general, executive-level jobs include business owners, presidents (or vice-presidents) of a company, and chief executive officers (CEOs)

FTSE 100 - the Financial Times Stock Exchange 100, also known as the FTSE 100 (or, informally, 'Footsie') is an index of the 100 companies listed on the London Stock Exchange with the highest- value shares. There are also FTSE 250 and FTSE 350 companies, which include the FTSE 100 index

GENDER DIVERSITY - gender diversity in the workplace commonly refers to an equal or near-equal ratio of men and women in a company

SOCIAL OR WELFARE POLICY - guidelines, principles, legislation, and activities that meet human needs for security, education, work, health and well-being

UNDERREPRESENTATION - Insufficient or disproportionally low representation. For example, if women are underrepresented on company boards then it means there are far fewer women than men at the top decision-making level
It was in 1997 when Marjorie Scardino became the first woman to head a FTSE 100 company. By $2011,12.5 \%$ of FTSE 100 board positions were held by women and, in 2018, that figure rose to $29 \%$. While the number of women on company boards is heading in the right direction in the UK, women at the top decision-making level are still underrepresented, with men making up the majority.

"Large businesses often have a board of directors that represents the interests of the company's owners or shareholders," says Dr Helen Kowalewska, based at the University of Oxford's Department of Social Policy and Intervention in the UK. "The board is responsible for making important business decisions, such as how to invest profit and setting company targets."

Different countries appoint directors to company boards in different ways. In most cases, it is the shareholders who vote on the directors they would like to hire (or fire). But, in some countries, employees can also vote; in others, the board of directors appoints new members.

Helen is a social policy analyst investigating the impact that government social policies have on female representation in the business world. Her goal is to understand why some countries do better than others and how the UK can improve gender diversity on company boards.

WHAT ARE THE BENEFITS OF HAVING WOMEN ON EXECUTIVE BOARDS?

Better female representation on boards has positive consequences throughout the company. In the first instance, a variety of perspectives, backgrounds and experiences can be key to a company's success, and one way to harness these varying perspectives is through gender diversity. Companies with genderdiverse boards are more likely to have a better understanding of their customers and clients, many of whom will be women. And this is not the only benefit. 

career. With family-friendly policies, like workfrom-home options and on-site childcare, women are more likely to stay in their jobs and progress up the career ladder.

Studies have also found that bringing more women into leadership positions can help tackle workplace sexual harassment. Worryingly, recent surveys have found that sexual harassment - unwanted sexual behaviours, such as sexual comments, touching, groping and assault - is commonplace across UK workplaces. A BBC survey in 2017 found that $40 \%$ of women and $18 \%$ of men had experienced unwanted sexual behaviour in the workplace. "Women in board roles are more likely to take claims of sexual harassment seriously and to push firms to do something about it, as they are more likely to have experienced sexual harassment themselves," says Helen. They are also less likely to be the perpetrators of sexual harassment. Therefore, getting more women into board positions can help to create safer workplaces for all. FEMALE REPRESENTATION?

The Hampton-Alexander Review, backed by include most of the Eastern European states plus the US, continue to lag far behind on women's board membership. They also have relatively ungenerous welfare states."

The second group consists of countries with voluntary regulations for board diversity. These regulations recommend that companies take action to increase female board representation, but there are no consequences if the company fails to do so. Voluntary boardroom quotas work better in countries with more generous welfare policies and legislation that supports working mothers (like Sweden has). Other countries with smaller welfare states and less support for women's employment (like Spain) have not been as successful with a voluntary approach.

\section{Finally, a third group of countries has} mandatory regulations for gender quotas in the boardroom. Companies that do not achieve a mandatory percentage of women on their board face fines or other penalties. Countries with mandatory regulations are the most successful at achieving a high level of gender diversity. Norway was the first European country to implement a mandatory quota for boards, which came into force in January 2008. France and Italy are among those that have since followed suit.

\section{WHAT CAN THE UK DO TO IMPROVE GENDER DIVERSITY ON COMPANY \\ BOARDS?}

The UK falls into the second group, where there are voluntary regulations in place for female board representation. But, as Helen's research has found, voluntary targets are not so successful in increasing female representation when broader policy supports for women's employment are lacking.

"For the UK's voluntary approach to be successful, a two-pronged strategy is needed," says Helen. "This is where the government applies pressure on companies to appoint more women to boards and enhances policy supports for working motherhood, as in Scandinavian countries." Social policy studies like Helen's are key to helping the government make these policy and societal improvements.

1. www.gov.uk/government/news/record-numberof-women-on-ftse-100-boards 


\section{ABOUT SOCIAL POLICY ANALYSIS}

The academic study of social policy focuses on how societies meet human needs (like education and healthcare), respond to inequalities, and bring about social change. It considers the role of government provisions (like laws, benefits and services) as well as the role of families, companies, charities and other organisations in the distribution and redistribution of resources and opportunities.

WHAT TOOLS DO SOCIAL POLICY ANALYSTS USE IN THEIR RESEARCH? Social policy analysts are social scientists. Like other social scientists, they use both qualitative and quantitative methods in their work. This might include carrying out surveys to determine people's beliefs and opinions, or analysing long-term business data to discover statistical trends and correlations.

Helen's research involves performing a literature review: reading all published data about a particular social policy issue and logically dissecting it to draw broad conclusions which are useful to policymakers. Helen has also used a technical method called fuzzy-set qualitative comparative analysis. This method allows her to compare how welfare state interventions and gender boardroom quotas interact in industrialised countries.
HOW CAN SOCIAL POLICY ANALYSIS HELP CHANGE THE WORLD FOR THE BETTER?

Social policy analysis seeks to find causal relationships between government policies and real-world outcomes. Put simply, social policy analysts figure out what actually works. The findings of social policy analysis are crucial in helping governments and institutions to decide which rules and incentives are effective to achieve positive outcomes for the people they govern. Analysts like Helen, who write articles and give interviews for the public, can also influence public opinion about what goals are worth aiming for and what steps government should take to achieve them.

\section{HOW TO BECOME A SOCIAL POLICY ANALYST}

- It is a good idea to gain some experience through an internship or voluntary work. For example, Helen's first experience in this field was collecting data for the 'Caught in the Act of Protest' research project. In the UK, Operation Black Vote, Citizens Advice Bureau, Adam Smith Institute, YouGov, W4MP (Working for an MP), and NatCen all offer internship and/or volunteer opportunities: guides.careers.sussex.ac.uk/politics/experience

If you are in the US, you could try an internship like the Library of Congress

Volunteer Internship Program (www.loc.gov/ crsinfo/opportunities/volunteer.html).

- You can read about Helen's career journey for inspiration, here:

www.southcoastdtp.ac.uk/my-southamptonresearch-journey-from-undergrad-topostdocl

- Getting involved with local government is also a great way to learn how policy is implemented in the real world.

- The average salary of a social policy analyst in the UK is $£ 36,000$

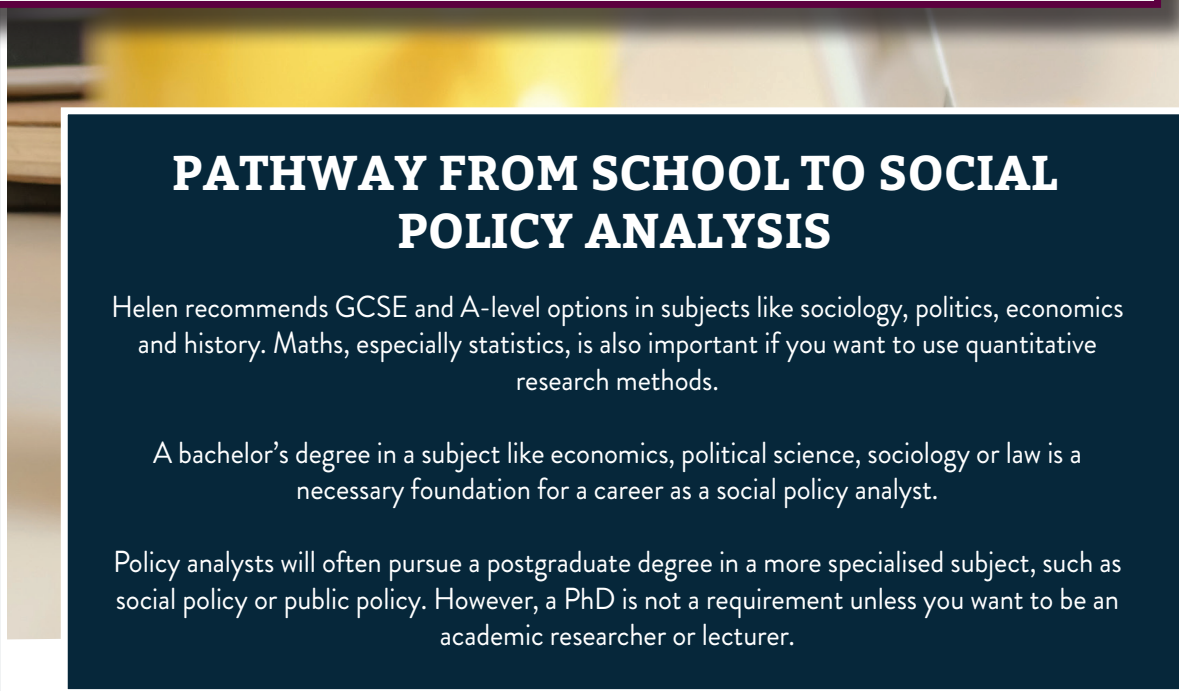

\section{HELEN'S TOP TIPS}

OI Make the most of any opportunities that come your way.

02 If money is a barrier, there are lots of funding opportunities available to support your university studies, especially at master's and $\mathrm{PhD}$ levels.

03 Mentorship is really, really important! Finding senior (women) academics who believed in me, challenged me and helped me to navigate the world of academia was crucial. 


\section{HOW DID HELEN BECOME A SOCIAL POLICY ANALYST?}

YOU HAVE A BSC DEGREE IN

POLITICS. WHO OR WHAT INSPIRED YOU TO STUDY POLITICS?

It had always been programmed into me that I would go to university. I went to a selective school where the emphasis was on academic attainment. There was a point when I considered not going to university, but after leaving school, moving out, and working in various temp job for a couple of years, I decided I would definitely like to go. I chose to study politics simply because I had taken it at A-level and really enjoyed it. But I had always been politically engaged. At home, I would often have debates with my dad growing up!

\section{DID YOU WANT TO BE A POLITICIAN} WHEN YOU WERE YOUNGER?

Not really. To be honest, I didn't know what I wanted to be. Once I had definitely decided
I wanted to go to university, I chose a subject that I found interesting - politics - and thought, I'll figure it out when I get there, which is indeed what ended up happening!

YOU ALSO HAVE AN MSC AND PHD IN SOCIAL POLICY. WHAT IS IT ABOUT SOCIAL POLICY THAT FASCINATES YOU?

I'm particularly interested in the ways in which social policies can help to reduce gender inequalities, especially in the workplace. For example, maternity leave policies are important so that women can keep their foot in the labour market and not be unfairly penalised for having children. But maternity leave can also reinforce certain inequalities. Time spent out of work can lead to missed opportunities for career development and employers may be more reluctant to hire women in assuming they are more likely to take career breaks. So, for me, it's really interesting to think about some of the unintended consequences of policies, too, and how we can resolve them for a fairer society.

WHAT DO YOU LIKE TO DO IN YOUR SPARE TIME?

I'm a keen runner and took part in the $\mathrm{New}$ Forest Marathon a couple of years ago. I find running a great way to de-stress and help my body catch up with my mind after a busy day of thinking. I also love baking for my family. Other than that, I enjoy spending as much time as possible with my husband and daughter and getting out in the fresh air and countryside.
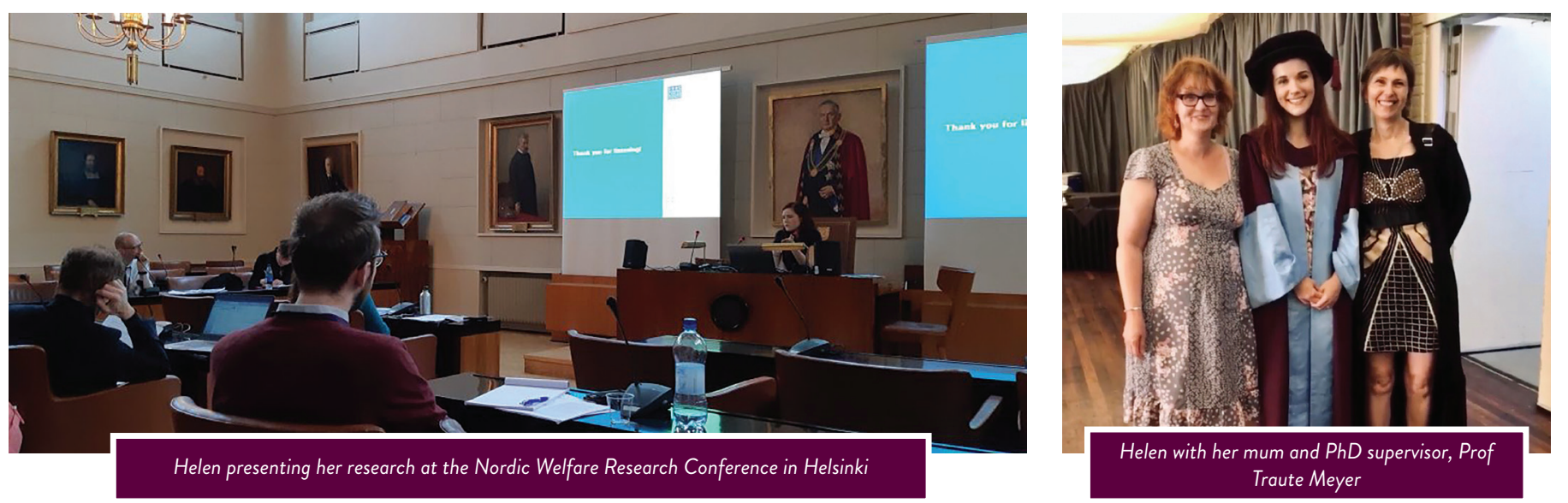